\title{
CARDIOVASCULAR REFLEXES IN TRACHEOSTOMISED TETRAPLEGICS
}

\author{
By P. Dollfus, M.D., and H. L. Frankel, M.B. M.R.C.P. \\ National Spinal Injuries Centre, Stoke Mandeville Hospital
}

\section{INTRODUCTION}

SUDDEN death associated with tracheostomy and with endotracheal suction has been reported in non-tetraplegics (Davis et al., 1953; Brattsröm, 1954; Nelson, 1957; Green, 1959). Arrythmias precipitated by endotracheal suction and inflation of endotracheal cuffs were described by Reid and Brace (1940), and deaths from this cause were reviewed by Stephenson (1958).

We have recently observed a tetraplegic patient in whom suction through a tracheostomy produced cardiac arrest. This case prompted us to investigate seven other patients with high spinal cord lesions and tracheostomies.

Case Report. A young man of 23 sustained a fracture dislocation $\mathrm{C}_{4} / 5$ in a car accident; this was followed by a complete tetraplegia below the level of $\mathrm{C}_{4}$ on the right and C6 on the left. The dislocation was reduced by skull traction and he was transferred to the National Spinal Injuries Centre two days after injury. On admission his condition was fair, he had no motor power in the right arm and only a weak deltoid and biceps on the left, the only sign of incompleteness below the level of C6 was a vague sacral sparing for touch. The upper lobe of his right lung was collapsed and his vital capacity was $750 \mathrm{ml}$. The skull traction was maintained, and there was no change in his condition in the next week.

Eight days after admission he developed a severe gastro-intestinal haemorrhage which continued intermittently for a further week until he died. In view of his condition he was treated conservatively; 35 pints of blood were given during the course of that week. On the second day of the bleeding he suddenly stopped breathing, became very pale, and

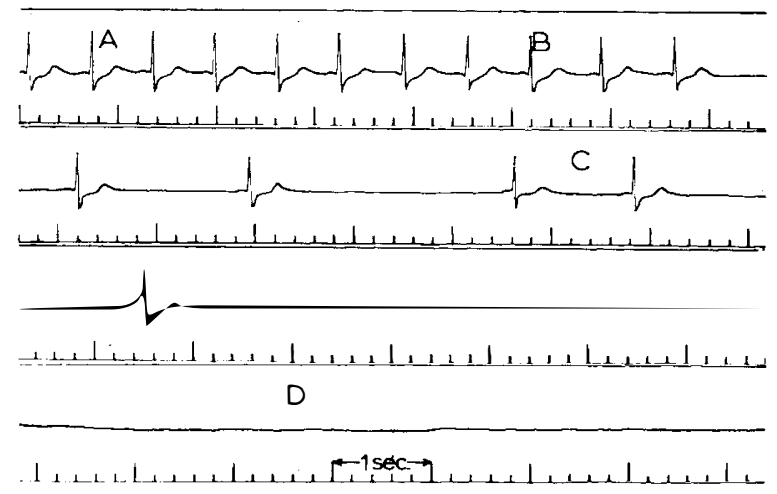

FIG. I

The beginning of the trace shows normal sinus rhythm, the positive pressure having been disconnected at (A).

(B) Suction started and immediately discontinued at

(C), when the irregular bradycardia was seen. (D) External cardiac massage started. 


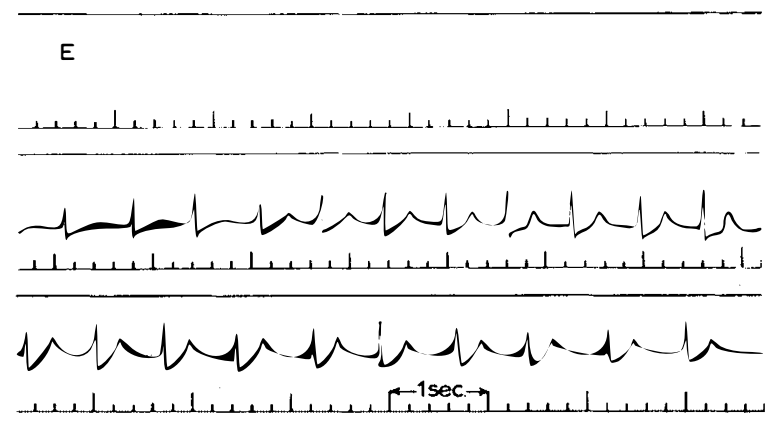

FIG. 2

Following 54 seconds of complete cardiac arrest, a needle connected to a syringe containing adrenaline was inserted in the left fourth intercostal space at (E) as soon as the needle penetrated the ventricular wall the heart was felt to beat and the needle was immediately withdrawn.

lost consciousness for I 5 minutes; there was no cardiac arrest. Three days after this (I6 days after injury), at a time when the gastro-intestinal bleeding seemed to have stopped, he suddenly stopped breathing and the heart stopped beating for 15 seconds. An immediate tracheostomy was performed, uneventfully, under local anaesthetic. Breathing was maintained by intermittent positive pressure.

Half an hour after the tracheostomy was performed he had a further cardiac arrest of 15 seconds. During that night he had 12 similar attacks of cardiac arrest lasting between 20 and 45 seconds each. One of these attacks was precipitated by blowing up the cuffed tracheostomy tube. All the other attacks were precipitated by endotracheal suction which was performed to keep the airway free. During that night the patient was unconscious with intervals of semi-consciousness. The next day the patient's condition was unchanged and as it was still essential to administer intratracheal suctions to remove secretions; this was done under ECG control. (Fig. I)

Although no $P$ waves are seen in the first few beats, these beats are supraventricular in type, closely resembling those preceding the cardiac arrest. When the $\mathrm{P}$ waves reappear there is no change in rhythm or rate; this suggests either changing level of nodal rhythm or that the $P$ waves were revealed by change in heart position. Severe ischaemic changes develop following the cardiac arrest. (Fig. 2)

The patient was then given $\frac{1}{100}$. of a grain of atropine intravenously and the procedure repeated after five minutes. In Figure 3 intratracheal suction was started (A) and continued until (B). This procedure has no significant effect on the ECG. Further aspirations were carried out during the next two hours under ECG control, and again, no effects were observed. He was maintained on injections of atropine $\frac{1}{2} 0_{0} .0$ of a grain subcutaneously four-hourly and there were no further periods of cardiac arrests although he still required frequent suction. He died suddenly the next day.

Post Mortem (Dr. C. R. Tribe). The heart showed no macroscopic abnormality apart from slight dilatation of the mitral ring. There was partial collapse of both lungs and there were pulmonary emboli in the arteries supplying the left lower lobe and right middle lobe (both deep calf veins contained ante-mortem thrombi); the trachea was quite healthy. Situated in lesser curve of the stomach and extending up the posterior wall was a large irregular acute ulcer, $\mathrm{I} \frac{1}{2}$ inches in diameter. There were two smaller ulcers in the pre-pyloric region. In the first part of the duodenum there was a deep penetrating ulcer in the bed of which lay an eroded vessel. The spinal cord looked nearly normal but on palpation showed a softening between 4 th and 5 th cervical segments. 


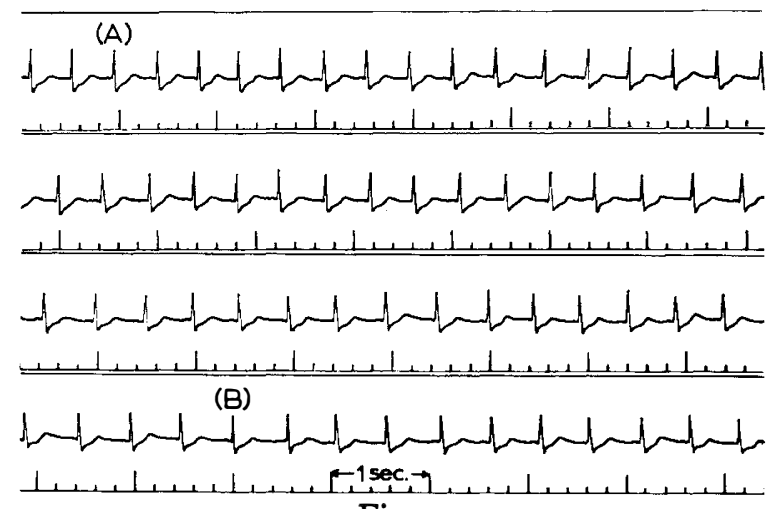

Fig. 3

\section{STUDIES ON SEVEN OTHER PATIENTS}

Seven other patients with traumatic lesions of the spinal cord (6 cervical, I upper dorsal ( $\left.\mathrm{T}_{5}\right)-5$ complete, 2 incomplete) were investigated. Tracheostomy had been performed 9 days to 7 weeks previously (average 4 weeks); the tracheostomies had been performed within three days of injury except in one case where it was done four weeks after injury. All the patients had therefore been recently injured, but apart from this were free of other complications and were receiving no drugs. Electrocardiograms were performed before, during and after endotracheal suction and in four patients in addition an endotracheal cuff was inflated. In three patients the investigation was repeated.

Results. The resting ECGs were within normal limits. All endotracheal manœuvres we performed on these patients did not produce any arrythmia. No changes in intervals or complexes seen. In four cases there was a slight increase in heart rate during and after suction of from 5 to Io beats per minute.

Examination of these patients under these conditions thus failed to show any similarity with the case of cardiac arrest we have described.

\section{DISCUSSION}

It is apparent from the protection given by atropine in our patient that the final mechanism of the cardiac arrest in this case was vago-vagal. Early work on vagal cardiac inhibition was done by Brodie and Russell (1900) who, using dogs, stimulated the central end of divided branches of the vagus electrically. Stimulation of the pulmonary branches produced the greatest cardiac inhibition and required a smaller stimulus than other branches of the vagus. Sloan (1950) stimulated the intact vagus of dogs at the lung root and found that when the animals were well ventilated electrical stimulation caused only prolongation of the P-R interval and downwards displacement of the pacemaker; however, when the animals were inadequately ventilated or asphyxiated similar stimulation caused cardiac arrest. Young et al. (195I) also using dogs stimulated the right vagus in the neck and found similar results and also found that hypercapnia alone enhanced the vagal effects and hypoxia alone diminished them. These authors attributed the enhanced vagal effect to respiratory acidosis which can enhance the action of acetylocholine (Gesell et al., 1942). 
Experimental work in man has of course been much more limited as almost all anaesthetised patients have been premedicated; for instance Morton et al. (1953) stimulated both ends of the vagus in patients in whom that nerve had been divided below the recurrent laryngeal nerve, they found ECG evidence of vagal action in only 2 out of 18 patients. However, all the patients had been premedicated with atropine or scopolamine.

Reid and Brace (1940) demonstrated varying degrees of cardiac inhibition produced by any mechanical irritation of the respiratory tract in patients lightly anaesthetised with cyclopropane or nitrous oxide; they suggested adequate premedication of all patients before introducing any mechanical device into the trachea. In a survey of I7IO cases of cardiac arrest Stephenson (1958) found that 64 cases occurred at the time when an endotracheal tube was inserted.

Davis et al. (I953), reporting I I miscellaneous tracheostomies, record four cases of sudden death during or immediately after the operation. They attributed these deaths to suffocation. Brattström (I954) described four cases of death following suction via a tracheostomy. He postulated that death may have been due to sudden lowering of intra-alveolar pressure; however, Green (I959) attributed death in five cases following tracheostomy to sudden reversal of a respiratory acidosis.

Pulmonary emboli have been shown to produce reflex cardiac inhibition in animals. This inhibition is prevented by atropine. (Scherf \& Schönbrunner, I937).

There were many factors predisposing to vagal cardiac arrest in the patient we have described, The prolonged bleeding and associated shock and continuous transfusion with citrated blood probably played a part. Pulmonary embolism probably caused the cardiac arrest which preceded the tracheostomy and may have sensitised the patient to further vagal stimulation. It is interesting to consider the part that the vagus may have played in the production of the multiple acute peptic ulcers and also the possible effect of these ulcers on the vagus.

It is apparent that cardiac arrest could well have developed in this case in the absence of the tetraplegia and our complete failure to demonstrate electrocardiographic changes in the other seven patients confirms this view. However, there are theoretical reasons to believe that the cardiac sympathetic may facilitate beats originating in the ventricles, or escape beats (Rothberger \& Winterberg, I9I I), and the total failure of our patient to exhibit ventricular escape beats may be due to absence of central control of the sympathetic in a tetraplegic.

In tetraplegics requiring tracheostomy under circumstances predisposing to cardiac arrest it is probably safest to give atropine before the operation and to perform endotracheal suction under ECG control when the atropine is wearing off. In this connection it is worth mentioning that a neurogenic ileus may occur in acute tetraplegics at the same time as the tracheostomy is required and that Prostigmin which is the usual treatment for the ileus may enhance vagal action on the heart.

\section{SUMMARY}

A patient with acute traumatic tetraplegia associated with severe bleeding from multiple peptic 'stress ulcers' is described. He was treated with blood transf usions ( 35 pints in one week) but his condition deteriorated after a pulmonary embolism and a tracheostomy was performed. Subsequently he had periods of 
cardiac arrest every time his tracheostomy was sucked out. Atropine prevented this, and the mechanism of the cardiac arrest is assumed to be vago-vagal. The patient died the next day.

Seven patients with high traumatic spinal cord lesions and tracheostomies (6 cervical, I upper dorsal) had ECGs performed before, during and after endotracheal suction. No arrythmias developed.

The mechanism of the cardiac arrest in this case is discussed with particular reference to the association with 'stress ulcers' and pulmonary embolism.

\section{ACKNOWLEDGEMENT}

We are grateful to Dr. L. Guttmann, under whose care all the patients were, and to Dr. A. Schott for their help.

\section{RÉSUMÉ}

Le cas d'un tétraplégique d'origine traumatique présenta deux semaines après l'accident des hémorragies dûes à des ulcères de 'stress' est présenté. Il fut traité par des transfusions sanguines ( 8 litres en une semaine) mais son état général s'aggrava à la suite d'une embolie pulmonaire et d'une trachéostomie. Par la suite, chaque fois qu'une aspiration endotrachéale s'avera nécéssaire celle-ci déclencha un arrêt cardiaque. Ces arrêts cardiaques purent être évités par l'emploi d'atropine et il est supposé que le facteur en cause était un reflexe vaguo-vagual. Le malade décéda une semaine après le début de ces symptômes.

Sept malades avec une lésion haute de la moëlle épinière et porteurs d'une trachéostomie ( 6 cervicales et I dorsale haute) furent éxaminés à l'aide d'un éléctrocardiogramme avant, pendant et après aspiration endotrachéale et ne présentèrent pas d'arythmies. Le méchanisme de ces arrêts cardiaques est discuté avec une référence particulière à l'association d'ulcères de 'stress' et de l'embolie pulmonaire.

\section{ZUSAMMENFASSUNG}

Ein Patient mit traumatischer Tetraplegie und schweren Blutungen von multiplen 'stress' Magengeschwüren wird beschrieben. Er wurde mit Bluttransfusionen (über I 8 Ltr. in einer Woche) behandelt aber nach einer Lungenembolie verschlechterte sich sein Allgemeinzustand und er musste tracheostomiert werden. Darnach hatte er wiederholten Herzstillstand sobald die Tracheostomie abgesaugt wurde. Atropin konnte dies verhindern; Vago-vagale Reflexe werden als die Ursache des Herzstillstands angesehen. Bei 7 Patienten mit hohen traumatischen Rückenmarksverletzungen und Tracheostomien ( 6 zervikal, I hoch dorsal) wurden Elektrokardiogramme vor, während und nach trachealer Absaugung gemacht. Arrhythmien entwickelten sich nicht. Die Ursachen des Herzstillstands werden diskutiert mit besonderer Berücksichtigung der Kombination mit 'stress' Magengeschwüren und Lungenembolie.

\section{REFERENCES}

BrattsRöm, S. (1954). Acta chir. scand. 108, I70.

Brodie, T. G., \& Russell, A. E. (I900). F. Physiol. 26, 92.

Davis, H. S. Kretchmer, H. E. \& Bryce Smith, R. (1953). F. Amer. med. Ass. 153, II 56. Gesell, R., Brassfield, C. R. \& Hansen, E. T. (1942). Proc. Soc. exp. Biol. Med. (N.Y.) 49, 464 .

GreEN, N. M. (1959). New Engl. F. Med. 261, 846.

Morton, D. R., Klassen K. P., Jacoby, J. J. \& Curtis, G. M. (1953). Surg. Gynec. Obstet. 96, 724 .

Nelson, T. G. (1957). Amer. Surg. 660, 750, 84I.

REID, C. L. \& BRACE, D. E. (I940). Surg. Gynec. Obstet. 70, I 57.

Rothberger, C. J. \& Winterberg, H. (I9I I). Arch. ges. Physiol. 142, I46.

SCHERF, D. \& SCHÖNBRUNNER, E. (1937). Klin. Wschr 16, 340.

SlOAN, H. E., (1950). Surg. Gynec. Obstet. 91, 257.

Stephenson, H. E. (1958). Cardiac Arrest and Resuscitation p. 73. St. Louis: Mosley.

Young, G. W., Sealy, W. C., Harris, J. \& Botwin, A. (I95I). Surg. Gynec. Obstet. 93, 5I. 


\section{Discussion}

Sснотт, E. A. (England) said they had of course proved that the cardiac standstill was a vago-vagal effect by the protective effect of atropine. This was the view held by most people though by no means universally, and there were good papers trying to show that the mechanism underlying it was hypoxia or hypercapnea or both. He thought that a paper by Shoemaker and his co-workers, which came quite close to the paper they had heard, might reconcile the two views. These authors reported five deaths, four in children after operation for congenital hearts and one in an adult also for a cardiac condition, and they all died after a seemingly successful operation, either at sucking out of an endotracheal tube or on extubation. These authors referred to a paper by Kirgin and others who found by oximeter studies that at the moment of suction one found an abrupt fall in oxygen saturation of the blood and they themselves confirmed this and put forward the idea that this deoxygenisation might sensitise the vagus resulting in the effect of cardiac standstill just at that moment.

Secondly, Dr. Dollfus had referred to a paper by Brodie and Russell-an old paper on dogs - and it might be of interest to recall that Einthoven with a co-worker Veeringer showed that morphia in dogs could produce disturbances of conduction in the heart, not sino-auricular but atrio-ventricular amounting to complete heart block, and they proved that this was of vagal origin by vagotomy and atropine.

Lastly, he asked would it not be advisable to include in one's observations other parts of the respiratory tract, larynx and pharynx, because disturbances of cardiac rhythm had been recorded with laryngoscopy and also after tonsillectomy, as well as cardiac standstill on moving a pack in the tonsillar fossa and attacks of Adams-Stokes invariably associated with swallowing.

GutTMANN, L. (England) said he had become very interested in this problem from another point of view: they had now found that there was an uninhibited vagal action in high cervical lesions in whom the sympathetic control was completely crippled. Quite a number of these cervical patients developed very soon what was called 'stress ulcers', and they had just admitted a patient-a very unfortunate man from the Royal Air Force who had broken his neck on somersaulting at the Royal Tournament-who had a complete $\mathrm{C}_{4} / 5$ lesion, in whom the whole sympathetic control had been completely knocked out. Five days after injury, he had started with a very profound gastric haemorrhage, and the question arose what was the aetiology of what was called 'stress ulcer'; was it also produced by an uninhibited action of the vagal innervation?

Schotт, E. A. (England) said he had forgotten to mention one point, which was that the cardiac arrhythmias seemed to occur much more often in light anaesthesia and the same authors had raised the point that one had to weigh very carefully whether to have light anaesthesia with the advantage of cough reflex and swallowing reflex or a deeper plane which would be more protective with regard to cardiac arrhythmias.

FRANKEL, H. (England) referring to the dosage of atropine, said that their current practice of giving $\frac{1}{1}{ }_{0}$ of a grain was already very much more than that given in other countries. Atropine was a respiratory depressant and it would be hard to justify larger doses at the moment, although people did sometimes give an additional intravenous dose when they were going to perform manœuvres on sensitive structures. 
Regarding the use of oxygen in the normal case with tracheostomy on positive pressure where they had to disconnect the suction, they did in fact use pure oxygen for a minute or so beforehand if possible and also before a turn, but if this had any effect on the heart rhythm he did not know. He would like to know if anyone else had observed untoward reactions in tetraplegics on manipulations with tracheostomy tubes and suction.

PAESLACK, V. (Germany) said that some time ago he had seen a tetraplegic four months after accident who had not only broken the spinal column at the level of $\mathrm{C} 4 / 5$ but had also sustained a severe brain injury. He had died just Io days ago. He had been unconscious for Io days but became conscious two days before he died. He was sucked out not from a tracheostomy tube but from a nose tube; he died immediately within three seconds. The pathological findings showed that the frontal brain was nearly totally divided from the other part of the brain, the spine had been broken in two places and there was deep haemorrhage in the cord.

Harris, P. (Scotland) complimented all the people who had taken part in the Symposium on the circulation of the spinal cord, anatomical, physiological and pathological. It had brought forward several problems and had answered several points. It had answered one or two of his points as a neurosurgeon in relation to complications that might arise during antero-lateral cordotomy and during anterolateral decompression of the spinal cord in relation to the vessels. With regard to disturbances of the radicular arteries at the vital points, especially in the different kinds of lateral decompression in the lower dorsal region, they had had at least one catastrophe where spinal cord infarction occurred, presumably because the radicular artery was damaged during operation. He thought that this operation was now going out and the anterior operation, usually in the dorsal region, was being applied. He would like to ask the pathologists about the pathology of spinal epidural abscess, because he thought that spinal thrombophlebitis was an important condition and this could and did occur traumatically and sometimes with permanent effects in spinal epidural abscess. They saw the same sort of thing in the brain.

He also brought up the point about haematomyelia; was this a true condition, was it actual haemorrhage or was it in fact a red infarct? He would like to mention the term 'arachnoiditis'. Phenol had been mentioned the previous day, and he thought this could be very dangerous given intrathecally and he thought that arachnoiditis might damage the vessels. follows

HARDY, A. G. (England), Chairman of the afternoon session, summarised as

(I) What was the influence of epidural abscess on vascular changes, particularly veins?

(2) What was haematomyelia, true, haemorrhagic or infarct?

(3) What was the influence of phenol and arachnoiditis?

(4) What experience was there on vascular spasm in cases of trauma?

Wolman, L. (England), referring to the first question about veins, thought the veins were thrombosed in epidural abscesses, and certainly in extensive thrombosis of the veins the cord was very severely damaged. He had shown a photograph the previous day of a thrombosed vein on the cord as a result of a chemical stimulus, and certainly sepsis could do the same sort of thing.

Secondly, with regard to the effects of chemicals on the arachnoid and on 
blood vessels, just to say that arachnoiditis produced the effect on vessels was simplifying the problem; it did seem that these chemicals could act on all forms of connective tissue whether the tissue was in the wall of a blood vessel or in the arachnoid. One certainly found arachnoid thickening but one did find specific effects on vessels which developed pari passu with the changes in the arachnoid, and although one had tended to think of the thickened arachnoid as causing a compressing effect on vessels he thought these two effects of a chemical were working at the same time. There was quite a lot of evidence to show that the cord itself was also affected if the concentration of the chemical in the cerebrospinal fluid was sufficiently great. He had an example of methylene blue having been introduced into the cord with death happening 36 hours later, and extending throughout the whole length of the cord into the brainstem was found a peripheral effect on the myelin, involving the superficial fibres both in the cord and brainstem. So, he thought these effects of chemicals reacted both on vessels and on connected tissue and probably also on other elements. Another factor, of which they had quite a lot of evidence, was an immediate effect on the actual axis cylinders of nerves, of roots of the cauda equina. They seemed to swell up very quickly after the introduction of an irritative chemical. Therefore, he did not think they could be too simple in their explanation of how a chemical attacked the spinal cord or its blood supply or coverings.

With regard to the third question, he did not have time to go into the various types of syringomyelia, but from their material they seemed to have evidence of three main types of haematomyelia occurring: (I) the generally recognised type where there was haemorrhage into a pre-existing syringomyelic cavity; (2) haemorrhage which was not quite so extensive as the syringomyelic cavity but involved perhaps eight or ten segments of the cord occurring in a man who was previously fit but had had a severe cord injury. When they examined the cord many years later they found big cavities extending several segments and lined by glial tissue but nowhere quite as thick as the gliosis around a syringomyelitic cavity; (3) this was the type he had shown on the slides, with a small cavity usually in the grey matter and usually containing red cells and necrotic debris. There might well be infarcts as well, but the tissue inside was so disorganised and there were so many red cells and destruction that it was pretty difficult to be sure that the mechanism was confined to grey matter, and this suggested that it had originated in the site where there had been a maximal haemorrhage as seen in the acute stage, of which he had shown examples.

Fourthly, with regard to vascular spasm, all he could say was that he had never come across this. It was impossible to analyse this pathologically, but if the vessels of the spinal cord were anything like the cerebral vessels he would think that spasm was an important factor in contributing to the amount of damage to the cord which occurred after an injury. Certainly in the cerebral vessels they had adequate evidence from angiography that spasm could affect vessels right down to the smaller branches, and he could see no reason why this should not apply to the spinal cord.

SCHAFER, E. (Germany) was glad that the problems of stomach bleedings had been mentioned because they had lost three young patients with high cervical lesions during the past year, and his question now was how often were stomach bleedings seen in high cervical lesions and what special methods of treatment had been developed beyond blood infusions? 
Guttmann, L. (England) replied that there were no statistics on ulcers occurring in acute high cervical lesions. It would, of course, be important to investigate these cases in the early stages, but this, as a rule, was not feasible. With regard to treatment, the main measure was the blood transfusion. In one of their cases they had called in the services of a general surgeon and he had indeed rescued the patient. In the case reported by Dollfus and Frankel, the surgeon declined to operate. He was quite right, for the patient was too critically ill and died.

Ross, J. C. (England) said that with regard to the cases of bleeding shortly after a high injury, although they had not yet done so they had in mind to use gastric cooling when such a case arose again. After all, the apparatus was not very complicated, they had it going in Liverpool at present for other cases and it seemed to him particularly suitable for that type of patient.

PAESLACK, V. (Germany) said they had used gastric cooling on such a case, but without any effect, and the patient died 24 hours later.

HARDY, A. G. (England) thought perhaps, as Chairman, he could have the last word. They had had 396 acute admissions in the last Io years, with nine cases of alimentary tract bleeding, two cases of haemorrhagic ulcerative colitis and three deaths in this series of nine.

\title{
CIRCULATORY REFLEXES IN SPINAL MAN
}

\author{
By J. R. Silver, M.B., B.S., M.R.C.P., Ed. \\ National Spinal Injuries Centre, Stoke Mandeville Hospital
}

THE reflex activity that is responsible for changes in muscle blood flow with posture and following the Valsalva manœuvre is believed to arise in low-pressure receptors rather than in arterial baroreceptors (Shepherd, 1963). While it has been established that the efferent side of these reflexes is by the sympathetic nervous system, the afferent side of these reflexes and their central connections are obscure.

Sharpey-Schafer (1956) has pointed out that if such reflex activity can be eliminated, it is much easier to understand the physiology of the circulation, since it is possible to differentiate between changes occurring which are central or reflex in origin and changes occurring that are local or mechanical in origin. It seemed that the study of a group of subjects who had sustained a complete physiological interruption of their spinal cords as a result of trauma above or at the level of the sympathetic outflow could offer a unique opportunity to determine which of these reflexes were spinal in origin, and which required the continuity of the brain stem, spinal cord and sympathetic chain for their elicitation.

The reflexes studied were the changes in the forearm blood flow in response to passive elevation of the legs, the Valsalva manœuvre and heating of the lower part of the body.

Clinical Material. Eight tetraplegic patients and three normal controls were studied. The level of the spinal cord lesion varied between $\mathrm{C} 6$ and $\mathrm{T}_{3}$. In each case complete loss of sensory and motor function as well as loss of control of bladder and bowel function indicated that there was a complete loss of functional continuity of the cord at the appropriate level. Five of the patients were complete lesions above the sympathetic outflow $\left(\mathrm{T}_{\mathrm{I}}\right)$, the remaining three patients had only 